\title{
DISINKRONISASI KEBIJAKAN PEMERINTAH INDONESIA DALAM PENANGANAN COVID-19
}

\author{
Amalia Azmi Sitorus*), Muhammad Firdaus Rahmadi \\ Universitas Paramadina \\ *)email: amaliaazmi895@gmail.com
}

Paper Accepted: 25 Maret 2021 Paper Reviewed: 25-31 Maret 2021 Paper Edited: 01-15 April 2021 Paper Approved: 25 April 2021

\begin{abstract}
ABSTRAK
Covid-19 adalah virus yang sudah dinyatakan sebagai Pandemi oleh WHO. Covid-19 yang sering dikenal dengan Virus Corona telah banyak mematikan manusia. Virus ini masuk lewat drop plet, namun virus ini juga bisa menular dan masuk ke dalam tubuh manusia melalui benda yang disentuh oleh orangorang yang terinfeksi virus ini. Covid-19 telah banyak memberikan efek terhadap beberapa sektor di dalam pemerintahan. Salah satu efek yang sangat berdampak ditinjau dari segi ekonomi. Pemerintah telah mengeluarkan beberapa kebijakan untuk memutus mata rantai penyebaran Covid-19 ini, namun kebijakan yang dikeluarkan pemerintah terkesan berubah-ubah sehingga masyarakat bingung mengapa sampai terjadi disinkronisasi aturan. Yang tentunya akan berdampak luas bagi aktivitas masyarakat. Penelitian ini menggunakan metode kualitatif dengan pendekatan teori analisis framing, analisis wacana, dan kebijakan publik. Dari pendekatan ini bisa diketahui bagaimana kebijakan pemerintah sampai tidak sinkron, apa yang menyebabkannya hingga dampak yang ditimbulkan. Tentunya ada banyak variabel yang membuat kenapa penanganan Covid-19 ini kerap berubah-ubah. Dari faktor ekonomi, politik, respon publik, ataupun persoalan lainnya.
\end{abstract}

Kata Kunci: Covid 19, Dampak Ekonomi, Kebijakan Pemerintah

\section{PENDAHULUAN}

\section{Latar Belakang}

Akhir tahun 2019, masyarakat dunia dikejutkan dengan adanya virus baru yang menjadi persoalan global dan berdampak sangat serius pada aspek-aspek kehidupan. World Health Organization (WHO), sebagai organisasi kesehatan dunia menetapkan wabah pandemi global dan menyebutnya sebagai COVID-19 (coronavirus disease 2019). Dalam waktu singkat, wabah ini kemudian menjadi pandemi dan menjalar ke seluruh dunia. Wabah ini didefinisikan sebagai penyakit berbahaya yang menyebar dengan cepat dan sering menyebabkan kematian (Emmeluth, 2005: 6). Wabah ini juga merupakan penyakit yang sangat serius dan dapat menyebabkan banyak kerusakan pada tubuh yang disebabkan oleh organisme mikroskopis yang disebut bakteri (Hardman, 2010: 11).

Menurut angka terbaru WHO, jumlah kasus Covid-19 di seluruh dunia telah melampaui 90 juta kasus, tepatnya mencapai 90.054.813 pada Rabu (13/1/2021). secara global, pada pukul 9:47 pagi pada hari Rabu (13/1/2021), ada 90.054.813 kasus Covid-19 yang dikonfirmasi, termasuk 1.945 .610 kematian, yang dilaporkan ke WHO. Amerika Serikat tetap menjadi negara dengan jumlah kasus dan angka kematian tertinggi di dunia, dengan 22.428.591 kasus yang dikonfirmasi dan 373.329 kematian dilaporkan ke WHO. Kemudian diikuti oleh India dengan 10.495.147 kasus dan 151.529 kematian, lalu Brasil, dengan 8.131.612 kasus dan 203.580 kematian. Negara yang juga terkena dampak parah adalah Rusia dengan 3.448.203 kasus, Inggris dengan 3.118.522 kasus, Prancis dengan 2.740.656 kasus, Italia dengan 2.289.021 kasus dan Spanyol dengan 2.111.782 kasus. Adapun jumlah korban tewas setelah tiga besar adalah Meksiko 134.368 kasus, Inggris 81.960 kasus, Italia 79.203 kasus, Prancis 67.368 kasus, Rusia 62.804 kasus, Iran 56.360 kasus, dan Spanyol 
52.275 kasus. Menurut kantor regional WHO, Amerika tetap menjadi wilayah yang paling terdampak Covid-19, dengan total 39.835.210 kasus terkonfirmasi dan 925.289 kasus kematian, diikuti oleh Eropa di mana 29.251.917 kasus terkonfirmasi dan 634.670 kasus kematian telah dilaporkan.

Sebelum namanya resmi ditetapkan oleh WHO sebagai COVID-19, beberapa sarjana sempat menamainya dengan 2019-nCOV dan novel coronavirus peneumonia (NCP) (Lu et al., 2020). World Health Organization (WHO), Maret 2020, menyatakan Covid-19 menjadi pandemi di seluruh dunia. Gejala Covid-19 antara lain; demam, batuk, sesak nafas, diare, sakit tenggorokan, kehilangan indera rasa, ruam kulit (WHO-Indonesia, 2020). Virus ini mengakibatkan kematian dengan cepat. Berjuta orang terjangkiti di seluruh dunia. Negaranegara di dunia berupaya sekuat tenaga untuk memutus mata rantai penyebaran COVID-19 sehingga sebagian negara akhirnya melakukan upaya penjarakan fisik dan sosial (social and physical distancing) (Wilder-Smith \& Freedman, 2020).

Indonesia menjadi satu negara yang terjerat virus tersebut. Data dari Satuan Tugas (Satgas) Penanganan Covid-19 hingga Kamis (20/5/2021) pukul 12.00 WIB, ada penambahan 5.797 kasus baru Covid-19 dalam 24 jam terakhir. Penambahan itu menyebabkan total kasus Covid-19 di Indonesia saat ini mencapai 1.758.898 orang, terhitung sejak kasus pertama diumumkan Presiden Joko Widodo pada 2 Maret 2020. Dengan demikian, jumlah pasien Covid-19 yang sembuh di Indonesia hingga saat ini mencapai 1.621 .572 orang. Akan tetapi, jumlah pasien yang meninggal setelah terpapar Covid-19 juga terus bertambah. Pada periode 19-20 Mei 2021, ada 218 pasien Covid-19 yang tutup usia, sehingga, angka kematian akibat Covid-19 mencapai 48.887 orang sejak awal pandemi.

Fakta ini sempat mencuatkan perdebatan di sejumlah kalangan, termasuk para peneliti dari Harvard University dan WHO yang telah memberikan peringatan terhadap Indonesia agar segera melakukan test massal dengan tujuan untuk menekan penyebaran virus ini secepatnya. Pada 2 Maret 2020, Presiden Joko Widodo (Jokowi) mengaku wabah Covid-19 sudah masuk Indonesia dengan ditemukannya tiga kasus positif terinfeksi virus tersebut. Penetapan status Pandemi Covid-19 oleh WHO berdasarkan jumlah penyebaran virus bertambah signifikan dan berkelanjutan secara global, hal ini direspon oleh Pemerintah Indonesia dengan menetapkan status wabah Covid-19 sebagai
Bencana Nasional pada tanggal 14 Maret 2020 yang tertuang dalam Keputusan Presiden Nomor 12 Tahun 2020 tentang Penetapan Bencana Non Alam Penyebaran Corona Virus Disease 2019 (COVID-19) sebagai Bencana Nasional. Dalam skala nasional, penanganan COVID-19 ini segera dikelola oleh Pemerintah Pusat langsung di bawah Presiden RI melalui Gugus COVID-19 yang secara berkala menyampaikan perkembangan dari waktu ke waktu. Presiden membentuk Gugus Tugas Percepatan Penanganan Covid-19 dalam rangka mengkoordinasikan kapasitas pusat dan daerah. Sejak Pemerintah Australia mengumumkan kasus pertama Covid-19 per 25 Januari 2020.

Pemerintah Indonesia bersikeras tidak ada kasus pasien positif sepanjang Januari-Februari 2020. James Massola, kontributor media dalam artikel berjudul 'The World's Next Coronavirus Hotspot Is Emerging Next Door', memaparkan perkembangan pandemi Covid- 19 di Indonesia disebut di bawah radar, karena hanya dalam delapan hari merekam lebih dari 1.000 kasus baru setiap hari. Massola mengutip data Worldometre yang menyebutkan Indonesia dalam kondisi mengkhawatirkan lantaran rasio tes Covid-19 rendah dan jumlah kematian tinggi (CNN Indonesia.com. (a)., 2020). Status darurat Covid-19 di Indonesia terus diumumkan oleh sejumlah kepala daerah dari tingkat gubernur, bupati, dan walikota di seluruh Indonesia.

Menilik kurva statistik korban yang terkena covid-19, angkanya terus bertambah dan bikin pemangku kebijakan mengambil tindakan strategis. Seperti menutup sekolah di beberapa daerah, mulai 16 Maret 2020 hingga pembatasan pusat ekonomi. Soal kebijakan transportasi, kendaraan masuk daerah yang tergolong zona merah juga dibatasi. Puncaknya, Pemerintah Indonesia memberlakukan Pembatasan Sosial Berskala Besar (PSBB) secara parsial maupun total untuk beberapa wilayah yang terdampak paling parah.

Sebagaimana halnya negara-negara lain yang sama-sama terdampak dan memberlakukan pembatasan aktivitas warganya, Pemerintah Indonesia juga melarang penyelenggaraan aktivitas massal dan kerumunan. Perusahaan-perusahaan ditutup, sekolah, kampus dan perkantoran juga merumahkan seluruh penghuninya. Pelabuhan, bandara, stasiun, terminal dibatasi, hotel, pusat perbelanjaan, pusat-pusat bisnis juga serupa tempat wisata, stadion olahraga semuanya ditutup. Bahkan rumah-rumah ibadah juga tidak diperbolehkan untuk menyelenggarakan kegiatan massal yang mengundang kerumunan. Secara bertahap, pemerintah daerah juga 
menutup akses jalan-jalan menuju dan dari luar kota, bahkan gang-gang tiap wilayah rukun warga, dikunci gembok dan dirantai disertai pemberitahuan status pembatasan aktivitas yang secara keseluruhan bertujuan untuk menekan penyebaran virus.

Media massa banyak memuat kritik terhadap pemerintah yang dinilai lamban dalam merespons, padahal seharusnya bisa lebih dini mengantisipasi kasus ini. Komunikasi yang buruk berdampak pada kebijakan yang tidak efektif. Namun ketidakpercayaan publik kepada pemerintah sudah terlanjur hadir. Pandemi adalah kondisi yang luar biasa, maka penanganannya juga harus luar biasa. Ketika negara lain sudah "full alert" menanggapi wabah Covid-19 ini, pemerintah Indonesia sempat terlihat kurang serius dan tidak siap ketika situasi tereskalasi sedemikian cepat (ABC Australia, 2020). Bahkan di awal penanganan pandemi, terjadi perbedaan data pasien Covid-19, antara Ikatan Dokter Indonesia (IDI) dan pemerintah. IDI pun meminta pemerintah bersikap transparan. Namun beberapa pihak banyak pula yang mensangsikan akurasi data yang disampaikan pemerintah karena berbeda dengan data yang dipunyai IDI.

Keraguan publik ini, antara lain disebabkan strategi komunikasi publik terkesan tidak transparan. Hal itu disayangkan banyak pihak Pemerintah dianggap meremehkan ancaman nyata dari pandemi ini bagi kesehatan publik. Padahal para ahli telah mengingatkan dari jauh hari kalau Covid-19 telah masuk Indonesia, tetapi pemerintah tak mau mendengar. Kesannya pemerintah tidak responsif dengan ancaman Covid-19 ini terlihat misalnya, sikap denial Presiden Jokowi awal Februari 2020 tentang kemungkinan wabah tersebut telah masuk ke Indonesia. Kata Presiden, ada dugaan 62 orang positif terinfeksi pada waktu itu, tetapi setelah dicek tidak terbukti ada yang positif. Bantahan presiden atas informasi sudah masuknya wabah tersebut tidak berdasarkan tes yang cepat dan masif, tetapi lebih atas dasar informasi dari anggota kabinet dan birokratnya. Terutama mantan Menteri Kesehatan Terawan Agus Putranto, yang mengklaim Covid-19 tidak akan menyebar luas di Indonesia. Dia bahkan berkelakar kalau Indonesia bebas dari Covid-19 berkat perlindungan Tuhan.

Pernyataan yang mirip dikemukakan oleh Wakil Presiden Ma'ruf Amin, yang juga seorang ulama. "Covid-19 tidak akan menyebar luas karena kita punya doa qunut," katanya. Bagi satu subkultur Islam, doa dipercaya memiliki kekuatan melindungi umat dari bencana, seperti wabah Covid-19. Pernyataan tersebut dinilai tidak etis disampaikan mantan Menteri Kesehatan dan wakil presiden karena dianggap sebuah guyonan yang tidak harus disampaikan pada kondisi genting. Pemerintah terkesan lambat dalam merespon masuknya Covid -19 ke Indonesia. Dalam berbagai kesempatan, seringkali pejabat dan menteri, Kepala BNPB, dan presiden Jokowi sendiri menyampaikan informasi yang berbeda-beda, sehingga membuat rakyat bingung. Sejumlah pejabat juga membandingkan Indonesia dengan negara lain yang segera kembali pulih. Begitupun dengan hubungan antara pemerintah pusat dan daerah sering diperbincangkan karena dalam praktiknya masih menimbulkan upaya tarik- menarik kepentingan (spanning of interest).

Ketidaksingkronan pemerintah pusat dan pemerintah daerah terlihat kasat mata dalam penanganan Covid-19. Urusan kesehatan yang didesentralisasikan kepada pemerintah daerah telah menyebabkan masing-masing daerah menyusun kebijakan sepihak dalam menghadapi penyebaran Covid-19. Sementara itu pemerintah pusat juga mengambil tindakan sendiri. Hal itu bisa dilihat saat pemerintah daerah yang lebih dahulu mengambil langkah antisipasi dan penanganan Covid-19. Misalnya, kebijakan lockdown lokal yang diambil Bupati Tegal sejak 23 Maret 2020 dengan cara menutup akses masuk kota dengan beton movable concrete barrier (MBC). Kebijakan Gubernur Papua yang melakukan penutupan akses keluar-masuk dari pelabuhan, bandara, darat, termasuk Pos Lintas Batas Negara sejak 26 Maret 2020. Kebijakan Gubernur Bali sejak 27 Maret 2020, yang meminta masyarakat tidak berkumpul, bekerja, belajar dan beribadah dari rumah saja. Pemerintah Pusat baru mengeluarkan Peraturan Pemerintah Nomor 21 Tahun 2020 tentang Pembatasan Sosial Berskala Besar Dalam Rangka Percepatan Penanganan Covid-19 pada tanggal 31 Maret 2020. Itu menimbulkan persoalan bagaimana pengaturan kewenangan antara pemerintah pusat dan pemerintah daerah dalam urusan penanganan pandemi Covid-19 terhadap kurangnya kesiagaan, kewaspadaan, kepekaan Pemerintah Indonesia atas penanganan pandemi. Pemerintah dinilai lamban, kurang memperhitungkan dampak wabah sejak awal. Kesan saling lempar antar lembaga pemerintah juga terasa di awal Pandemi. Kepala daerah cenderung bertindak sendiri dan memunculkan kesan ketidakseragaman pusat-daerah. Pemerintah Pusat yang seharusnya preventif, justru mengambil tindakan yang dinilai tidak responsif. 
Seperti lamban dalam menutup akses keluar-masuk Indonesia, serta memberikan stimulus di bidang pariwisata guna menarik masuknya wisatawan asing. Akibatnya daerah mengambil langkah insitiatif guna menerapkan protokol Covid-19 dan PSBB di daerahnya.

Tindakan ini bikin geregetan pemerintah pusat untuk kemudian menegur pemerintah daerah. Publik menilainya antar pemerintah ada beda pendapat dan tidak memiliki desain kebijakan penanganan pandemi. Kementerian bergerak sendiri tanpa panduan solid dalam memberikan informasi kepada publik (BBC News Indonesia, 2020; Narasi, 2020). Selain tidak singkron antar pusat-daerah, masalah lain dalam penanganan Covid-19 adalah terkait implementasi kebijakan. Dimana petugas dianggap kurang sigap, sanksi tak jelas, rendahnya disiplin, jadi penyebab kenapa aturan tidak berhasil. Soal kebijakan pemerintah kerap membingungkan, lantaran adanya tumpang tindih aturan hingga saling sanggah. Musababnya, aturan yang dibuat kerap kontraproduktif. Misalnya salah satu kebijakan yang pernah dilontarkan pemerintah Indonesia ialah usia 45 tahun ke bawah boleh beraktivitas seperti biasa. Ketua Gugus Tugas Penanganan Covid-19 Doni Munardo menjelaskan kalau aturan tersebut dibuat guna mengurangi beban pemutusan hubungan kerja (PHK).

Belum ada sepekan, kebijakan ini dibantah Menteri Koordinator Bidang Perekonomian Airlangga Hartarto. Menko menerangkan jika dalam pemerintah belum menetapkan aturan untuk karyawan di bawah 45 tahun kembali bekerja. Sekali lagi penanganan covid-19 di Indonesia tidak dapat dikatakan baik-baik saja. Terdapat banyak sekali blunder yang dilakukan oleh pemerintah dalam proses penanganannya. Lembaga Penelitian, Pendidikan dan Penerangan Ekonomi dan Sosial (LP3ES) bahkan merinci terdapat 37 pernyataan blunder yang dilontarkan oleh pemerintah selama pandemi (Mawardi, 2020). Pernyataanpernyataan blunder seperti yang telah dipaparkan di atas dan beberapa di antaranya yakni tanggapan Menteri Koordinator Politik, Hukum, dan Keamanan (Menkopolhukam) Mahfud MD dan Menteri Koordinator Perekonomian Airlangga Hartarto tentang corona tak masuk Indonesia karena perizinan yang berbelit-belit. Tambahan lagi, candaan Wakil Presiden Ma'ruf Amin tentang susu kuda liar dapat menangkal virus corona. Sikap tersebut menjadi satu bagian dari serangkaian upaya komunikasi penanganan covid-19 yang harus dikaji secara keseluruhan baik dari fase pre- crisis, crisis, dan post crisis.
Pemerintah dianggap terlambat membuat menagani pandemi virus corona di Indonesia. Masyarakat membandingkan pemerintah lebih memilih menyelamatkan sektor ekonomi dibandingkan kesehatan. (https://ayoyogya.com/read/2020/). Pada Februari 2020, Presiden Jokowi terlihat lebih peduli dan tertarik pada peluang ekonomi saat wabah ini muncul di negara- negara lain ketimbang masalah kesehatan publik.

Dengan adanya pandemi di negara lain, diharapkan mereka akan melihat Indonesia sebagai destinasi wisata dan investasi. Presiden meminta kabinet menyiapkan seluruh instrumen fiskal maupun moneter untuk memperkuat daya saing dan keunggulan ekonomi pada masa pandemi yang sedang terjadi di negara lain. Permintaan ini disampaikan pada tanggal 25 Februari 2020 dalam pengarahan anggota kabinet sehubungan dengan isu wabah tersebut. Pada waktu itu, Covid- 19 bukan hanya sudah menyebar di Wuhan, Tiongkok tetapi juga sudah menyebar ke banyak negara lain, seperti Korea Selatan, Jepang, Iran, Filipina, Italia, Amerika Serikat, dll, hanya sekitar satu minggu sebelum presiden mengakui Covid-19 sudah masuk Indonesia.

Sehubungan dengan permintaan presiden untuk memanfaatkan peluang ekonomi pada masa wabah Covid-19, Mantan Menteri Parawisata dan Industri Kreatif Wisnu Tama membuat kebijakan yang memberikan insentif bagi turis atau pengunjung karena turisme merosot akibat Covid-19. Dorongan yang sama juga disampaikan Menteri Keuangan Sri Mulyani, "Ayo berwisata." Presiden sendiri yakin bahwa insentif bagi turisme itu tidak akan menyebarkan Covid-19.

Di tengah ketidakjelasan kebijakan tersebut, pemerintah malah mempertimbangkan konsep new normal, yang bisa dimaknai perubahan perilaku atau kebiasaan untuk tetap menjalankan aktivitas seperti biasa namun dengan selalu menerapkan protokol kesehatan di tengah pandemi COVID-19. Presiden bahkan sempat mengumumkan larangan mudik lebaran mulai dari tahun 2020 hingga 2021. Larangan tersebut mulai diberlakukan, Jumat 24 April 2020 sesuai dengan yang disampaikan Menhub.

Anehnya, tak lama setelah diumumkan kebijakan itupun dirubah dengan mengeluarkan surat edaran yang mengatur larangan mudik untuk semua transportasi. Isinya tak jauh beda dari tahun sebelumnya, yang mana aturan tersebut dibuat saat kondisi tidak ada pandemi. Soal aturan mudik, kondisi tersebut terulang tahun ini, dimana pemerintah pusat mengeluarkan kebijakan larangan mudik. 
Sayangnya komunikasi antar pemerintah tidak satu suara. Presiden melarang mudik, sedang Menhub mengatakan tidak ada larangan. "Terkait dengan mudik 2021 pada prinsipnya pemerintah lewat Kemenhub tidak akan melarang. Saya akan koordinasi dengan Gugus Tugas bahwa mekanisme mudik akan diatur bersama dengan pengetatan, dan lakukan tracing pada mereka yang hendak berpergian," ujar Menteri Perhubungan Budi Karya Sumadi saat rapat kerja dengan komisi V DPR RI, Selasa (16/3/2021).

Di sisi lain dikutip dari

https://www.kompas.com/tren/read/2021

pemerintah menetapkan larangan mudik untuk Lebaran 2021 pada 6-17 Mei mendatang. Keputusan larangan ini ditetapkan dalam rakor yang dipimpin oleh Menko PMK Muhadjir Effendy bersama sejumlah menteri dan lembaga negara pada 26 Maret 2021. Kebijakan yang dikeluarkan terlihat tidak kontras antara aturan yang dikeluarkan satu sama lain. Hal itu memperlihatkan adanya ketidaksinkronan antara kebijakan yang dikeluarkan pemerintah dan menyebabkan masyarakat semakin bingung. Soal larangan mudik ini, banyak yang khawatir untuk merayakan Idulfitri di kampung karena akan menyebarkan Covid-19 ke berbagai daerah di tanah air.

Mudik adalah tradisi yang kuat dan melibatkan jutaan orang melakukan perjalanan antarkota, antardesa, antardaerah, bahkan antarpulau. Kalau kebijakan yang tegas diberlakukan, misalnya dengan kebijakan lockdown, maka mudik bisa dilarang atau dicegah. Akan tetapi, kebijakan itu tidak diambil dan pemerintah hanya bisa menghimbau agar warga tidak mudik. Namun setelah dievaluasi, secara agak terlambat pemerintah melarang mudik tanpa payung lockdown setelah Covid-19 menyebar di tanah air.

Pertanyaan yang muncul kemudian adalah mengapa pemerintah membuka akses untuk wisatawan luar masuk dan berwisata ke Indonesia dengan memberikan intensif untuk para turis tetapi menghimbau masyarakat untuk tidak mudik. Pernyataan ini membuat masyarakat bingung dan kesal atas yang disampaikan pemerintah. Pemerintah Indonesia juga terkesan kurang tegas dan kurang cepat dalam merespons ancaman wabah ini. Pertanyaan itu muncul berdasarkan pantauan atas ucapan dan kebijakan pemerintah. Seperti studi penelitian sebelumnya seperti yang dilakukan oleh Handini Andriani (2020) pada penelitian yang berjudul "Komunikasi Pemerintah dalam Penanganan Pandemi Covid19" menyebutkan bahwa ditemukan beberapa kurang efektifnya komunikasi yang disampaikan pemerintah mengenai penanganan covid-19 ini diantaranya kurang akuratnya data dan informasi yang disampaikan pemerintah kepada publik, minimnya sosialisasi yang dilakukan pemerintah terhadap beberapa isu, rendahnya kepercayaan publik kepada pemerintah, hingga kurang efektifnya komunikasi pemerintah antar lembaga.

Permasalahan kurang akuratnya data dan informasi antara lain dikemukakan Ahmad Arif yang mencontohkan data kematian yang tidak sesuai dengan panduan WHO (Arif, 2020). Selain itu data bantuan sosial juga dinilai belum akurat (Siagian, 2020). Permasalahan minimnya sosialisasi dan rendahnya kepercayaan masyarakat menimbulkan sejumlah permasalahan seperti penolakan rapid test (Astutik, 2020), dan fenomena pengambilan paksa jenazah penderita Covid-19. Hal itu, menurut akademisi Nanyang Technological University Singapore, Sulfikar Amir, adalah bukti ketidakpercayaan masyarakat (Syambudi, 2020). Sedangkan permasalahan kurang efektifnya komunikasi organisasi pemerintahan dapat diketahui dari perbedaan kebijakan antarorganisasi pemerintahan yang dikomunikasikan ke publik. Beberapa hal di antaranya yaitu tarik menarik kewenangan antara pusat dengan daerah (Mandasari, 2020), pemberian ijin masuk bagi Tenaga Kerja Asing (TKA) di tengah pandemi Covid-19 (Pohan, 2020), dan pengaturan pengoperasian ojek daring (Jannah, 2020).

Handini Andriani juga menyebutkan bahwa DPR perlu mendorong pemerintah untuk segera membenahi dan melakukan revisi terhadap pedoman manajemen komunikasi pemerintahan dalam penanganan pandemi Covid-19. Selain itu, optimalisasi peran Kominfo guna meningkatkan komunikasi organisasi pemerintahan dan untuk meningkatkan upaya sosialisasi, sesuai dengan Pasal 2 Peraturan Presiden Nomor 54 Tahun 2015 tentang Kementerian Komunikasi dan Informatika, serta Instruksi Presiden Nomor 9 Tahun 2015 tentang Pengelolaan Komunikasi Publik yang menempatkan Menkominfo sebagai koordinator dalam diseminasi kebijakan strategis kegiatan dan program pemerintah pusat.

Penelitian serupa juga dilakukan oleh Laode Harjudin (2020) pada sudut pandang yang berbeda dengan judul Dilema penanganan Covid-19: antara legitimasi pemerintah dan kepatuhan masyarakat. Laode Harjudin menilai Pemerintah Indonesia telah banyak mengeluarkan kebijakan untuk menangani Covid-19 namun persoalan utama dalam upaya 
penanganan wabah Covid-19 adalah pemerintah kesulitan memperoleh kepatuhan masyarakat untuk menaati kebijakannya sesuai protokol kesehatan. Berbagai kebijakan ataupun himbauan pemerintah tentang protokol kesehatan terkesan diabaikan atau tidak dipatuhi masyarakat. Dalam upaya penanganan wabah Covid-19, pemerintah mengalami krisis legitimasi sehingga kesulitan memperoleh kepatuhan masyarakat untuk mentaati kebijakannya terkait penanganan wabah tersebut. Berbagai kebijakan ataupun himbauan pemerintah tentang protokol kesehatan terkesan diabaikan atau tidak dipatuhi masyarakat. Secara prosedural formal, pemerintah memiliki legitimasi yang sah melalui pemilu dengan asumsi banyaknya pemilih menandai luasnya persetujuan terhadap penggunaan kekuasan pemerintahan yang dikendalikannya.

Namun asumsi prosedural tidak selamanya benar karena sulit menemukan pengaruh signifikan antara legitimasi dalam pemilu dengan legitimasi kebijakan yang dihasilkan. Biasanya dukungan yang diperoleh dalam proses kebijakan tidak mencerminkan legitimasi dalam pemilu. Secara teoritis, pemilu sekedar memberikan kewenangan formal kepada pemerintah yang hanya melegitimasi kedudukan pemerintah sebagai penentu kebijakan, bukan substansi kebijakan yang hendak diberlakukan pemerintah.

Krisis legitmasi pemerintah tidak dapat dilepaskan dengan pencintraan politik berlebihan. Pencintraan politik merupakan bagian dari fenomena "imagologi" masyarakat era kapitalisme lanjut. Pemerintah yang hanya mengandalkan pencitraan rentan terhadap berbagai krisis yang menimpanya. Hal itu terjadi di Indonesia ketika menghadapi wabah pandemik global Covid-19. Terbiasa dengan politik pencitraan yang sekedar mengkamuflase realitas, maka ketika pemerintah melakukan penanganan virus corona tampak tidak memiliki grand design yang jelas sehingga terjadi tumpang tindih dan terkesan tidak konsisten. Dengan model kebijakan seperti ini agak sulit mengharapkan kepatuhan masyarakat.

\section{Rumusan Masalah}

Berangkat dari studi-studi sebelumnya yang telah dilakukan peneliti terdahulu, studi ini akan menganalisa mengapa terjadi disinkronisasi kebijakan yang dikeluarkan pemerintah melalui lembaga-lembaga negara, serta bagaimana solusi yang disampaikan pemerintah karena disinkronisasi kebijakan yang dikeluarkan banyak mempengaruhi stabilitas ekonomi dan politik di Indonesia. Jika dilihat dari studi-studi sebelumnya yang juga membahas tidak efektifnya komunikasi pemerintah yang mempengaruhi tingkat kepercayaan masyarakat serta perlunya evaluasi komunikasi pemerintah dan ikut andilnya DPR Komisi 1 dalam melibatkan Kominfo untuk memperjelas segala kebijakan yang dikeluarkan pemerintah.

\section{Tujuan Penelitian}

Tujuan penelitian ini memberikan evaluasi terhadap komunikasi yang disampaikan pemerintah terhadap kebijakan yang dikeluarkan karena terkesan banyak nya ketidak jelasan dan simpang siur terhadap kebijakan yang sampaikan dan menyebabkan masyarakat bingung. Diharapkan dapat memberikan gambaran atau respons yang jelas dari keragaman kebijakan yang dikeluarkan dalam mengatasi Covid-19. Penelitian ini juga berfokus menganalisa pengaruh yang ditimbulkan pada situasi ekonomi dan politik dikarenakan adanya disinkronisasi kebijakan yang dikeluarkan.

\section{METODE PENELITIAN}

Penelitian ini menggunakan penelitian kualitatif dengan pendekatan sejumlah teori, seperti kebijakan publik, analisis wacana serta analisis framing. Data dan sumber yang diperoleh dari penelitian merupakan informasi yang dikutip dari berbagai jurnal terkait hingga media secara online dan website resmi pemerintah mengenai kebijakan pemerintah dalam penanganan Covid- 19, terutama masalah komunikasi yang disampaikan ke publik. Selain itu sumber juga diambil dari buku-buku, ataupun naskah-naskah yang berhubungan dengan penelitian terkait komunikasi pemerintah mengenai Covid-19.

Maraknya kasus ini tentunya membuat sejumlah penelitian yang dilakukan oleh sejumlah aspek keilmuan. Dari sudut pandang kesehatan, kebijakan publik, komunikasi, politik, dan lain sebagainya. Harapannya hasil dari penelitian ini bisa memberikan masukan kepada pemerintah tentang pengelolaan komunikasi agar informasi yang disampaikan agar tidak menimbulkan kesimpangsiuran. Tidak singkron informasi punya dampak besar, terutama di tingkat masyarakat paling bawah. Dikarenakan aturan yang dibuat, langsung dirasakan oleh seluruh masyarakat, dan masyrakat lapisan paling bawah memiliki dampak terbesar. 


\section{PEMBAHASAN}

\section{Disinkronisasi Kebijakan Penanganan Covid-19}

Dewasa ini, terhitung mulai 31 Desember 2019 hingga kini pandemic Covid-19 belum berakhir. Coronavirus adalah keluarga besar virus yang menyebabkan penyakit mulai dari gejala ringan sampai berat. Setidaknya ada dua jenis coronavirus yang diketahui menyebabkan penyakit yang dapat menimbulkan gejala berat seperti Middle East Respiratory Syndrome (MERS) dan Severe Acute Respiratory Syndrome (SARS). Coronavirus Disease 2019 (COVID-19) adalah penyakit jenis baru yang belum pernah diidentifikasi sebelumnya pada manusia. Virus penyebab COVID-19 ini dinamakan Sars-CoV-2 (KEMENKES, 2020). Karakter virus Corona sangat berbeda dengan jenis penyakit epidemik lainnya seperti kolera, pes, influenza, flu burung, dan lain-lain. COVID-19 ini sangat menyiksa manusia. Jika dia sudah menjangkiti orang, bukan hanya orang/warga/pasien yang terinfeksi Corona yang diisolasi oleh pemerintah, tetapi seluruh warga masyarakat akan turut diisolasi, baik warga yang sakit maupun warga yang sehat. Tempat karantina di rumah sakit bagi yang sudah terinfeksi, sementara yang sehat, akan dikarantina di rumah masing-masing secara mandiri. Isolasi mandiri dilakukan untuk mencegah dan menghindari penyebaran virus Corona meluas ke masyarakat. Namun, pandemi COVID-19 membuat hampir semua orang kalang-kabut menghadapinya. Persoalan menjadi sangat serius karena pandemi ini menjadi disrupsi sehingga kita perlu mengenali, mengatasi, dan mencegahnya agar penyakit itu segera berakhir.

Untuk mencegah penyebaran dan penularan virus ini, pemerintah membuat serangkaian kebijakan untuk menanganinya. Ada tertulis, ada pula tidak tertulis. Kebijakan yang tertulis, seperti Undang-undang (UU), Peraturan Pemerintah Pengganti UndangUndang (PERPU), Peraturan Pemerintah (PP), Peraturan Presiden (PERPRES), Peraturan Menteri (PERMEN), Peraturan Daerah (PERDA), Peraturan Bupati (PERBUP), Peraturan Walikota (PERWALI), dan lain-lain. Termasuk di dalamnya Surat Keputusan (SK), dan surat yang berasal dari pemerintah. Sedangkan kebijakan yang tidak tertulis bentuk mengajak untuk mematuhi protokol kesehatan. Umumnya disampaikan tokoh masyarakat, tokoh adat, tokoh budaya, tokoh agama. Contoh kebijakan tertulis seperti: KEPPRES No. 11/2020 tentang Penetapan Kedaruratan
Kesehatan Masyarakat Corona Virus Disease 2019 (COVID-19), PERPU Nomor 1 Tahun $2 \mathrm{O} 2 \mathrm{O}$ Tentang Kebijakan Keuangan Negara dan Stabilitas Sistem Keuangan untuk Penanganan Pandemi Corona Virus Disease 2019 (COVID19) dan/atau dalam rangka Menghadapi Ancaman yang Membahayakan Perekonomian Nasional dan/atau Stabilitas Sistem Keuangan; PP Nomor 21 Tahun 2020 Tentang Pembatasan Sosial Berskala Besar Dalam Rangka Percepatan Penanganan Corona Virus Disease 2019 (COVID-19), Surat Edaran No. 57/2020 Tanggal 28 Mei 2020 Tentang Perpanjangan Pelaksanaan Kerja dari Rumah/Work From Home (WFH) bagi Aparatur Sipil Negara (ASN) hingga 4 Juni 2020; Keputusan Presiden (KEPPRES) No. 12 Tahun 2020 tentang Penetapan Bencana Nonalam Penyebaran Corona Virus Disease 2019 (COVID-19) Sebagai Bencana Nasional, dan lain- lain.

Merespon tren perkembangan penyebaran dan penularan Corona yang terus meningkat, sejak tanggal 17 April 2020 Presiden mengumumkan COVID-19 sebagai bencana nasional melalui KEPPRES No. 12 Tahun 2020. Data dari Satuan Tugas (Satgas) Penanganan Covid- 19 hingga Kamis (20/5/2021) pukul 12.00 WIB, ada penambahan 5.797 kasus baru Covid- 19 dalam 24 jam terakhir. Penambahan itu menyebabkan total kasus Covid-19 di Indonesia saat ini mencapai 1.758 .898 orang, terhitung sejak kasus pertama diumumkan Presiden Joko Widodo pada 2 Maret 2020. Dengan demikian, jumlah pasien Covid-19 yang sembuh di Indonesia hingga saat ini mencapai 1.621.572 orang. Akan tetapi, jumlah pasien yang meninggal setelah terpapar Covid-19 juga terus bertambah. Pada periode 19-20 Mei 2021, ada 218 pasien Covid-19 yang tutup usia, sehingga, angka kematian akibat Covid-19 mencapai 48.887 orang sejak awal pandemi. Pasca penetapan COVID-19 sebagai pandemi, reaksi masyarakat beragam. Ada warga yang merasa takut, marah, panik, bingung, dan sedih (Utami, 2020). Virus Corona membuat warga masyarakat mengalami trauma dan suasana jiwa terancam dan ketakutan (threat and fear).

(Abdullah, 2020) mengidentifikasi ada empat jenis trauma yang disebabkan oleh coronavirus yaitu: pertama, trauma individual yang muncul dalam bentuk "social withdrawal" di mana seseorang yang dicurigai tertular coronavirus atau korban pemutusan hubungan kerja cenderung mengisolasi diri dari kelompok dan lingkungan sosial; kedua, trauma individual yang bersifat "histeria"; ketiga, trauma psychologis yang bersifat "violence act"; dan keempat, trauma psikologis yang bersifat 
"collective attach" sebagai respons atas kepanikan massal yang dialami komunitas (Sigit, 2020). Dampak virus ini sangat besar, bersifat global, dan massif. Ia tidak hanya mempengaruhi tingkat kesehatan masyarakat secara umum, namun juga mempengaruhi aktivitas ekonomi, sosial, psikologis, budaya, politik, pemerintahan, pendidikan, olahraga agama, dan lain-lain. Karena itu dibutuhkan kebijakan pemerintah yang tepat untuk mencegah dan mengatasi virus Corona ini. Kebijakan yang diperlukan bukan hanya kebijakan untuk mencegah dan menyembuhkan pasien yang terinfeksi Corona, tetapi juga kebijakan untuk mengatasi dampak sosial, psikologis, dan ekonomi yang ditimbulkan oleh virus Corona.

Kebijakan (policy) adalah prinsip atau cara bertindak yang dipilih untuk mengarahkan pengambilan keputusan. Kebijakan merupakan instrumen pemerintah, bukan saja dalam arti government yang hanya menyangkut aparatur Negara, tetapi juga governance yang menyentuh pengelolaan sumberdaya publik. Kebijakan pada intinya merupakan keputusan-keputusan atau pilihan-pilihan tindakan yang secara langsung mengatur pengelolaan dan pendistribusian sumberdaya alam, finansial dan manusia demi kepentingan publik (Suharto, 2008). Banyak definisi mengenai kebijakan publik, kebanyakan ahli memberi penekanan pada pembuatan keputusan atau ketetapan pemerintah untuk melakukan suatu tindakan yang dianggap akan membawa dampak baik (good impact) bagi warga negaranya. (Bridgeman, 2004) mengatakan bahwa kebijakan publik mengandung arti: "whatever government choose to do or not to do". Artinya kebijakan publik adalah apa saja yang dipilih oleh pemerintah untuk dilakukan atau tidak dilakukan.

Dengan demikian, kebijakan merupakan suatu ketetapan yang memuat prinsip- prinsip untuk mengarahkan cara-cara bertindak yang dibuat secara terencana dan konsisten untuk mengatasi masalah dan untuk mencapai tujuan tertentu. Pemimpin publik (public leaders) harus mampu membuat kebijakan untuk mencapai "common good". Namun ironisnya dalam situasi krisis, tidak semua pemimpin publik bisa menunjukkan kepemimpinan yang memadai, yang berakibat pada tergerusnya legitimasi kepemimpinan, bahkan bisa menyebabkan krisis kepercayaan terhadap system (Farazmand, 2009). Untuk diketahui bahwa kepemimpinan tidak cukup untuk dimiliki oleh seorang aktor atau elit negara atau daerah karena setiap kebijakan outputnya adalah bagaimana implementasi kebijakan itu diterapkan.
Menurut Jones (dalam La Ode Muhammad Elwan, S. and A. Pramusinto, 2011), Implementasi kebijakan mudah dimengerti secara teoritik dan konseptual, namun tidak senantiasa demikian dalam bentuknya yang kongkrit, karena pelaksanaannya secara nyata bukanlah sesuatu yang mudah. Proses implementasi bukan proses mekanis dimana setiap aktor akan secara otomatis melakukan apa saja yang seharusnya dilakukan sesuai skenario pembuat kebijakan. Artinya bahwa, ia merupakan proses yang rumit, diwarnai benturan kepentingan antaraktor yang terlibat, sehingga tujuan, target, dan strategi implementasi dapat berkembang. Berbagai faktor juga dapat membawa penundaan, penyalahgunaan wewenang, atau penyimpangan arah kebijakan (La Ode Muhammad Elwan, S. and A. Pramusinto, 2011).

Termasuk implementasi kebijakan pemerintah dalam pencegahan dan penanganan pandemi COVID-19 di Indonesia. Pemerintah Indonesia telah banyak mengeluarkan sebuah kebijakan publik yang pada akhirnya membuat masyarakat bingung dengan banyaknya disinkronisasi kebijakan yang dikeluarkan. Jika (Bridgeman, 2004) mengatakan bahwa kebijakan publik mengandung arti: "whatever government choose to do or not to do". Artinya kebijakan publik adalah apa saja yang dipilih oleh pemerintah untuk dilakukan atau tidak dilakukan. Namun pada kenyataannya hari ini banyak kebijakan publik yang dikeluarkan pemerintah namun sedikit masyarakat yang memberi perhatian untuk melaksanakan kebijakan yang dikeluarkan. Berbagai kebijakan pemerintah untuk mencegah penyebaran penularan virus Corona agar tidak menyebar luas di dalam masyarakat, yang telah diimplemetasi selama masa penularan wabah COVID-19 adalah sebagai berikut: kebijakan berdiam diri di rumah (Stay at Home); kebijakan pembatasan sosial (Social Distancing); kebijakan pembatasan fisik (Physical Distancing); kebijakan penggunaan alat pelindung diri (Masker); kebijakan menjaga kebersihan diri (Cuci Tangan); kebijakan bekerja dan belajar di rumah (Work/Study From Home); kebijakan menunda semua kegiatan yang mengumpulkan orang banyak; kebijakan Pembatasan Sosial Berskala Besar (PSBB); hingga terakhir, kebijakan pemberlakuan kebijakan New Normal.

Kebijakan pemerintah yang berubah-ubah mengindikasikan kurang siapnya penanganan Covid-19. Bisa juga kita menyebut pemerintah gagap mengatasi masalah. Jika ditarik ke belakang sejak virus ini menyebar, pemerintah 
seperti tidak bisa mengatasinya, walaupun sudah ada beberapa langkah kebijakan yang diambil. Fakta di lapangan berbeda dengan aturan yang dibuat. Hal tersebut diperparah dengan pernyataan para menteri yang cenderung kontroversial. Misal, corona tidak masuk ke Indonesia karena urus izinya ribet. Belum lagi candaan Menteri Perhubungan yang menyebut masyarakat Indonesia suka makan nasi kucing makanya kebal sama virus.

Lebih aneh lagi, ketika semua negara mulai menutup pintu masuk orang asing, pemerintah malah memberikan diskon besar untuk wisatawan asing yang ingin berlibur ke tanah air. Dari sederetan peristiwa tersebut mengindikasikan kalau apa yang dibuat oleh pemerintah dari awal memang sudah tidak siap mengatasi persoalan tersebut. Jangan heran jika membuat kebijakan ada kesan terburu-buru tanpa perencanaan yang matang. Hal itu tentunya berpengaruh terhadap kebijakan yang dikeluarkan. Pemerintah saat ini berkejaran dengan waktu. Harus segera mengatasi virus corona agar dampak ekonominya tidak semakin besar. Ditambah lagi peringatan dari sejumlah asosiasi pengusaha sudah memberikan sinyal soal kekuatan mereka jika pandemi ini berlarutlarut. Dimana kekuatan mereka hanya sanggup hingga Juni 2020. Asumsi tersebut berdasarkan uang yang dikeluarkan tanpa ada pemasukan.

\section{Wacana Covid-19}

Kajian mengenai analisis wacana umum digunakan untuk membahas sejumlah hal berkaitan dengan komunikasi. Melalui wacana yang dilempar ke publik biasanya akan mendapatkan respon. Dari respon ini dapat melihat sejauh mana wacana itu ditampilkan. Dari gagasan yang dilempar ke publik ini dapat diketahui apa yang diinginkan oleh pelempar gagasan tersebut. Biasanya yang menguasai wacana itu juga bisa memonopoli gagasan. Pemerintah memiliki kekuatan untuk menguasai wacana dengan media yang bisa dikontrolnya. Maka itu jika dikaitkan dengan sejumlah kebijakan pemerintah dalam penanganan Covid19 dapat dikorelasi. Terutama dalam melempar sebuah wacana. Semisal kebijakan pada awalawal Covid-19 mulai merebak. Seperti membuat diskon besar-besaran untuk industri pariwisata. Ada dua hal kenapa wacana ini dimunculkan, pertama, menarik potensi uang dengan kebijakan tersebut karena akan mendatangkan banyak wisatawan. Wacana ini cukup berani lantaran dibuat saat negara lain menutup semua akses untuk warga negara asing, pemerintah Indonesia membuka keran secara besar-besaran.
Kedua, kebijakan ini memberi pesan bahwa Covid-19 tidak perlu dikhawatirkan karena sudah bisa diatasi oleh pemerintah. Tujuan asalnya mencegah kepanikan, tetapi menuai kontroversi karena dilakukan ketika virus ini mulai merebak ke seluruh dunia.

Wacana bisa berarti objek atau ide yang diobrolkan secara terbuka kepada publik sehingga berdampak pada pemahaman tertentu. Dapat juga dimaknai rangkaian tindak tutur yang mengungkapkan sebuah hal dan disajikan secara teratur, sistematis, dalam satu kesatuan koheren. Wacana dapat dimaknai sebuah teks yang bermakna serta punya efek pada dunia nyata. Lewat wacana juga ada kontrol dan kekuasaan yang beroperasi melalui kontruksi sejumlah pengetahuan. Sayangnya ketika pemerintah membuat wacana terkait penanganan Covid-19, kontrol yang dilakukannya tak satu arah. Buktinya komunikasi antar instansi saja masih berantakan.

Dari isu terkait mudik, hubungan antara daerah dan pusat, hingga kebijakan yang berjalan sendiri-sendiri. Tidak sinkronnya wacana satu dengan yang lainnya tentu berdampak kepada implementasinya yang tidak berjalan sesuai dengan yang diinginkan oleh pemerintah. Kuncinya pada kepemimpinan satu arah, dimana presiden sebagai puncak dari kuasa bisa mendelegasikan keinginannya kepada para bawahan. Ketika hal ini tidak terjadi tentu ada persoalan dalam kebijakan pemerintah. Ketika wacana yang dituangkan dalam teks mengandung tanda ataupun makna perlu adanya satu komunikasi. Dalam artian, corong komunikasi harus terpusat, tidak boleh kemana-kemana.

Pengungkapan teks bisa artikan juga seperangkat tanda yang ditransmisikan dari seorang pengirim ke penerima lewat medium tertentu ataupun tanda-tanda tertentu. Ada juga simbol-simbol yang bukan hanya referensial tapi juga produktif dan kreatif. Simbol yang dihasilkan ini terepresentasi melalui bahasa, moralitas, hukum dan lainnya, yang tidak hanya mengacu pada sesuatu, juga menghasilkan perilaku, nilai-nilai dan ideologi.Dalam pemikiran Recouer, pengertian teks hanya pada tulisan yang mungkin bisa didiskusikan. Apakah teks itu rekaman dari sebuah wacana, seperti transkripsi seminar, itu juga bisa kita maknai sebagai wacana yang diterapkan dari tulisan. Itu merupakan sebuah gagasan. Gagasan yang dituangkan kemudian menjadi wacana dimaknai ada keinginan terselip dari sang pencentus. Ketika sudah menjadi opini publik, bisa langsung diekskusi ketika responnya baik atau 
positif. Kita menyebut publik diasosiasikan masyarakat. Meski bukan keseluruhan masyarakat, tetapi bagian kelompok yang memiliki kepedulian terhadap sebuah wacana tertentu.

\section{Framing Informasi Covid-19}

Kata framing bagi kalangan yang bekerja di bidang media sudah tidak asing lagi. Bahasa tersebut sudah menjadi santapan sehari-hari. Framing atau bingkai adalah ruh dari sebuah pemberitaan. Dalam setiap framing ada ide, ideologi, kepentingan, ekonomi, maksud, ataupun tujuan. Dalam teks tersebut terdapat ideologi, kepentingan, hingga hegemoni. Jadi tidak bebas nilai. Althusser mendefinisikan menjadi dua kategorisasi. Yakni Ideologi State Appartus (ISA) dan Represif State Apparatus (RSA). Lewat media, hegemoni, kekuasaan coba dilanggengkan lewat kata-kata, pendidikan.

Media berperan cukup besar bagaimana pelanggengan kekuasaan itu berjalan. Tuchman (1978) membuat definisi bahwa the news frame organize every day reality and the news frame is part and parcel of everyday reality: it is an essensial feature of news. Dengan kata lain, framing merupakan konstruksi atau pendefinisian oleh media mengenai realitas taupun peristiwa yang terajdi dalam masyarakat. Oleh karena itu, media framing dinilai dapat mempengaruhi secara sistematik bagaimana khalayak memahami peristiwa ataupun sebuah realitas.

Salah satu yang menjadi prinsip analisis framing adalah jurnalis bisa menerapkan standar kebenaran, matriks objektivitas, serta batasanbatasan tertentu dalam mengolah dan menyuguhkan berita. Dalam mengkonstruksi sebuah realitas, wartawan cenderung menyeratakan pengalaman serta pengetahuannya yang sudah mengkristal menjadi semata interpretasi. Dengan cara ini wartawan cenderung membatasi ataupun menyeleksi sumber berita, menafsrkan komentar sumber bertita, serta memberikan porsi yang berbeda dengan tafsir atau perspektif yang muncul dalam wacana media. Dalam praktiknya, framing dijalankan oleh media dengan menyeleksi isu tertentu dan mengabaikan isu lain, serta menonjolkan aspek isu tersebut dengan menggunakan pelbagai stategis wacana, penempatan yang mencolok, pengulangan, pemakaian grafis untuk mendukung dan memperkuat penonjolan, pemakaian label tertentu ketika menggambarkan orang atau peristiwa yang diberitakan.
Harusnya pemerintah bisa satu suara dalam hal penanganan Covid-19. Terutama dalam memframing sebuah informasi. Kementerian Kominfo sebagai garda terdepan dalam penyampaian informasi sepertinya kurang berperan. Contohnya tidak ada edukasi kepada masyarakat terkait Covid-19 pada awal-awal virus ini merebak. Yang ada sebaliknya saling sanggah kalau masalah virus bisa teratasi dengan baik. Harusnya dengan kekuatan yang dimiliki dapat membingkai sebuah informasi positif dalam isu Covid-19. Misalnya, memberikan edukasi kepada masyarakat terkait virus tersebut dengan menyebarkan pemberitaan yang mendidik, bukan sebaliknya menimbulkan rasa percaya diri kalau virus itu tidak bisa masuk dengan argumen-argumen kurang ilmiah. Seperti masyarakat Indonesia tidak kena virus karena suka makan nasi kucing.

Maraknya informasi yang beredar memang bikin pemerintah tidak bisa mengkontrol satu persatu. Media sosial kini sudah hampir dikonsumsi masyarakat luas. Tetapi dengan sejumlah langkah serta kuasa yang dimiliki, tentunya bisa dilakukan. Seperti dengan menertibkan berita hoax, menutup situs-situs yang ditengarai menyampaikan informasi menyesatkan, hingga melakukan propaganda besar-besaran dalam Covid-19. Paling utama adalah satu suara dalam penanganan virus ini.

Dari framing ini kita bisa melihat beritaberita tentang Covid-19. Terutama yang menyangkut soal pernyataan-pernyataan kontroversial yang dikeluarkan oleh pejabat negara, dari tingkat kepala daerah, menteri, hingga presiden. Misal definisi kata mudik dan pulang kampung yang sempat heboh. Pernyataan tersebut menjadi persoalan karena Presiden Jokowi mengatakan bahwa mudik dan pulang kampung berbeda. Dimana mudik dilarang sementara pulang kampung boleh. Sikap itu menimbulkan masalah dikarenakan merebak saat pemerintah melakukan kebijakan larangan mudik. Pernyataan ini menarik dan bisa dieksplorasi oleh media dalam membingkai pemberitaan tentang larangan mudik.

\section{KESIMPULAN}

Covid-19 atau yang dikenal dengan Virus Corona merupakan wabah yang tidak biasa. Banyak orang yang terjangkit Virus tersebut tanpa memperlihatkan gejalanya. Bahkan terkadang tidak banyak yang menyadari jika gejala tersebut timbul maka hanya terlihat seperti penyakit flu biasa. Namun tidak disangka Virus ini sangat berbahaya. Tidak hanya membahayakan kesehatan manusia, Virus 
corona telah banyak melumpuhkan berbagai bidang sector dalam pemerintahan. Mulai dari sektor pariwisata, politik hingga ekonomi. Sector ekonomi disini adalah sisi yang paling dirugikan, Laporan yang dirilis dalam OECD pada Maret 2020, menyatakan bahwa GDP Global diprediksi akan jatuh 2,4 persen pada 2020. Pertumbuhan GDP Indonesia menurun dari lima persen menjadi 0,2 persen.

Banyak pedagang yang menutup tokonya, hingga yang paling berdampak terjadinya penurunan penumpang pada ojek online. Hal ini menimbulkan banyak pengangguran dikarenakan banyak para karyawan perusahaan yang "dirumahkan" dan kondisi ini mangkin mempersulit masyarakat. Tidak sampai disitu, seharusnya para politisi yang seyogiyanya ikut turun andil dalam membantu masyarakat meringankan beban merka dalam situasi Covid19 ini. Namun ternyata itu hanya sebatas ekspektasi, para elit politik tidak terlihat membantu meringankan beban masyarakat atau konsituennya yang dianggap perlu untuk diperhatikan.

Ya, beginilah raut wajah perpolitikan di Indonesia namun jika kondisi sekarang tidak dalam wabah covid-19 mungkin para politisi tersebut sudah turun ke jalan atau ikut andil tapi bukan untuk membantu meringankan beban masyarakat tapi untuk memasang spanduk dalam momentum pilkada serentak.

Efek yang ditimbulkan akibat Covid-19 ini tidak hanya memperlihatkan kerugian dari segi ekonomi dan wajah politik namun karena efek yang ditimbulkan oleh virus ini sangat luar biasa maka pemerintah mengambil langkah untuk pencegahan Virus Corona ini agar tidak menimbulkan efek yang lebih parah. Kebijakan tersebut dimulai dari karantina wilayah, penutupan lemabaga pendidikan bahkan beberapa perusahaan memberlakukan "Work From Home" untuk mengantisipasi perluasan penyebaran Virus Corona ini. Jika diperhatikan dalam beberapa media, kebijakan yang dikeluarkan pemerintah sempat berubah-ubah hal ini menyebabkan kebingungan terhadap masyarakat sendiri.

\section{DAFTAR PUSTAKA}

Aud. (2020). Tanggapi Tumpang Tindih Peraturan Menteri soal Covid-19, Jokowi: Harusnya Satu Garis Sama Semuanya, https://wow.tribunnews.com/2020/04/24/ta nggapi-tumpang- tindih-peraturan-menterisoal-covid-19-jokowi-harusnya-satu-garissama-semuanya, (Diakses 11 Desember 2020).
Eriyanto. (2001). Analisis Wacana, Pengantar Analisis Teks Media. LKIS. Yogyakarta. Sobur, Alex. 2001. Analisis Teks Media, Suatu Pengantar untuk Analisis Wacana, Analisis

Garjito, Dani. (2020). Kelakar Menteri Airlangga: Izinnya Berbelit-belit, Virus Corona Tak

Masukhttps://www.suara.com/news/2020/ 02/15/141802/kelakar-menteri-airlanggaizinnya- berbelit-belit-virus-corona-takmasuk (Diakses 20 Desember 2020).

https://nasional.kompas.com/read/2020/04/23/1

5152141/jokowi-bedakan-mudik-dan-

pulang- kampung-ini-tanggapansosiolog?page=all (Diakses 26 Desember 2020).

https://news.detik.com/berita/d-4967416/inidaftar-37-pernyataan-blunder-pemerintahsoal corona-versi-lp3es (Diakses 27 Desember 2020)

Hadiwaryono, Wibowo. (2020). Kerugian Ekonomi Nasional Akibat Pandemi Covid19. Baskara: Journal of Business and Entrepreneurship, 2(2), 1-10.

Burhanuddin, Khairul Ikhsan, Muhamad Nur Abdi. (2020). Ancaman Krisis Ekonomi Global Dari Dampak Penyebaran Virus Corona (Covid-19). AkMen : Journal Stiendoel Indonesia.ac.id, 2(1), 90-98.

Sanur, Dabora. (2020). Wacana Kebijakan Lockdown dalam menghadapi Covid 19 di Indonesia. Pusat Penelitian badan Keahlian DPR RI, 12(6), 25-30.

Very. (2020). Masyarakat Bingung Akibat Pemerintah Tak Konsisten Buat Kebijakan Terkait Covid 19.

https://indonews.id/artikel/29068/Masy arakat-Bingung-Akibat-Pemerintah-TakKonsisten-Buat-Kebijakan-Terkait-Covid19/ (Diakses 3 November 2021)

Yunus, Nur Rohim, Annisa Rizki. (2020). Kebijakan Pemberlakuan Lockdown Sebagai Antisipasi penyebaran Corona Virus Covid 19. Salam: Jurnal Sosial\& Budaya Syar'i FSH UIN Syarif Hidayatullah Jakarta, 7(3), 227-238

Sandi, Fery. (2020). Alarm Pengusaha, Hanya Kuat Tahan dari Corona Sampai Juni. https://www.cnbcindonesia.com/news/202 00407221703-4-150453/alarm-pengusahahanya- kuat-tahan-dari-corona-sampaijuni, (Diakses 12Desember 2020).

Saroh, In Nalin. (2020). Kebijakan Berubahubah, DPR Nilai Pemerintah Tidak Konsisten Mengakhiri COVID-19, https://m.rilis.id/amp/Kebijakan-Berubahubah-DPR-Nilai-Pemerintah-Tidak- 
Konsisten- Mengakhiri-COVID-19, (Diakses 11 November 2020).
Siaran Pers Kementrian Keuangan Republik Indonesia SP - 27 /KLI/2020. 